Paedagogia Christiana

I/27 (201 I) - ISSN 1505-6872

Stanisław Radoń ${ }^{*}$

Kraków

\title{
Skuteczność metody dialogicznej w katechezie (eksperymentalne studium empiryczne)
}

\section{Wprowadzenie}

Od wielu lat w pedagogice toczy się dyskusja dotycząca celów edukacyjnych oraz metod występujących w ciagu procesów nauczania-uczenia się, a prowadzących do osiagania świadomie zakładanych celów. Wielu pyta, czy najważniejszym celem dydaktyki ma być przekazanie samej wiedzy uczniowi (akcent na intelekt i społeczne przystosowanie się), czy raczej troska o jego wszechstronny rozwój (uwzględnienie w procesie edukacji człowieka sfery emocji, ciała, wartości i duchowości, prowadzących do zakładanej twórczej samodzielności podmiotu). Na gruncie tych dyskusji powstało wiele ciekawych propozycji teoretycznych, które uwzględniają znaczenie wszechstronnego rozwoju ucznia w procesie edukacji.

Wydaje się jednak, że w praktyce pedagogicznej i katechetycznej istotnym elementem jest sam przekaz wiedzy oraz skuteczne wyegzekwowanie jej od uczniów. Nauczyciel, stosując celowo różne metody pedagogiczne, przynaglany skomplikowanymi i zmieniającymi się wymaganiami programowymi a niejednokrotnie w poczuciu utraty „władzy nad uczniami” - zapewne nieświadomie - podejmuje różne próby „wymuszenia” skuteczności dydaktycznej. Właśnie szczególnie tym metodom grożą tak zwane „błędy

* Ks. dr Stanisław Radoń (UP JP2), teolog i psychoterapeuta, nauczyciel dyplomowany Zespołu Państwowych Szkół Plastycznych w Krakowie. 
zimne” nauczyciela ${ }^{1}$. Do „błędów zimnych” zalicza się takie zachowania nauczyciela, jak: rygoryzm (bezwzględne egzekwowanie poleceń, pedanteria, sztywność ocen, stawianie bardzo dokładnie określonych, niepozostawiających swobody wymagań, formułowanie ocen negatywnych), ścisłe kontrolowanie postępowania ucznia (egzekwowanie posłuszeństwa), agresja (atak słowny bezpośredni lub pośredni, fizyczny lub symboliczny, zagrażający lub poniżający w stosunku do ucznia), hamowanie aktywności (przerywanie, zakazywanie własnej aktywności ucznia przez fizyczne lub symboliczne zachowanie własne), obojętność (dystans wobec spraw ucznia, okazywanie braku zainteresowania dla jego aktywności) oraz eksponowanie siebie (koncentrowanie uwagi ucznia na walorach wychowawcy, potrzebach, odczuciach wtórnych wobec aktualnych potrzeb i odczuć ucznia, chęć imponowania, wyróżniania się, obrażanie się) $)^{2}$.

Konsekwencją tych błędów są zmiany w strukturze emocji uczniów (dyskomfort psychiczny, lękowa motywacja podejmowania działań, pesymistyczna postawa wobec świata, niska samoocena albo wygórowana w postaci narcystycznej). Te błędy prowadzą w dalszej konsekwencji do blokowania samodzielności ucznia, jego krytycznego myślenia oraz pogłębiania się niedojrzałości i indolencji twórczej³ ${ }^{3}$ Emocjonalne odrzucenie ucznia („,błędy zimne") jest lękotwórcze (zaniża samoocenę ucznia, wzmacnia poczucie niekompetencji, poczucia winy). Rygoryzm, żądanie bezkrytycznego posłuchu, pedantyczność kontroli, niedopuszczanie odstępstwa od wprowadzonej normy i żadnego sprzeciwu sprawiaja, że uczeń rezygnuje z własnych dążeń, reaguje bojaźliwie, bezwiednie podporządkowuje się woli nauczyciela $\mathrm{i}$ innych dorosłych. Tłumiona aktywność ucznia budzi w nim świadomie i nieświadomie reakcje protestu, wyzwala różne formy zachowań konformistycznych (podporządkowanie pozorne, któremu towarzyszy maska dwulicowości i nieszczerości) i aspołecznych.

Wyniki wielu badań potwierdzają relatywnie częste występowanie takich błędów pedagogicznych w trakcie stosowania metod tradycyjnych ${ }^{4}$. Coraz częściej podejmuje się krytykę tradycyjnych metod pedagogicznych ${ }^{5}$.

${ }^{1}$ E. Jarosz, E. Wysocka, Diagnoza psychopedagogiczna. Podstawowe problemy i rozwiqzania, Warszawa 2006, s. 296-300.

2 Szeroka i systematyczna klasyfikacja i opis błędów popełnianych w ramach oddziaływań pedagogicznych - por. A. Gurycka, Bład w wychowaniu. Warszawa 1990.

${ }^{3}$ R. Wiechnik, Intelektualne i kreatywne aspekty zdolności do uczenia się, Lublin 1996, s. $68-74$.

${ }^{4}$ Omówienie wyników różnych badań dotyczących błędów pedagogicznych - por. M. Śnieżyński, Zarys dydaktyki dialogu, Kraków 1997, s. 146-156.

${ }_{5}$ Zob. J. Bagrowicz, Towarzyszyć wzrastaniu. Z dyskusji o metodach i środkach edukacji religijnej młodzieży, Torun 2006; W. Sikorski, Psychoterapia grupowa różnych pokoleń, Warszawa 2002. 
Również opracowania teoretyczne sugerują konieczność systematycznego stosowania różnych metod aktywizujących uczniów, ze szczególnym uwzględnieniem założeń pedagogiki dialogu ${ }^{6}$, psychopedagogiki twórczości $^{7}$ oraz katechetyki antropologicznej i dialogiczno-konfesyjnej ${ }^{8}$. Pojawiaja się nowe opracowania teoretyczne oraz tworzone są w oparciu o nie nowe metody pracy twórczej z uczniami ${ }^{9}$. Zakłada się w nich, że nie da się osiągnąc celu wychowawczego bez stworzenia możliwości dialogu i dyskusji. Możliwość dialogu i dyskusji pojawia się wtedy, kiedy nauczyciel gotowy jest zrezygnować z komfortu bycia nieomylnym ekspertem, wzorem moralnym i dyrektywnym organizatorem.

Zarzuty stawiane nowym metodom to rezygnacja $\mathrm{z}$ wymagań wobec ucznia i popadanie w tak zwane „błędy ciepłe” nauczyciela ${ }^{10}$. „Błędy ciepłe” polegają na następujących mechanizmach: uległość (spełnianie zachcianek ucznia, rezygnacja i obniżanie wymagań stawianych uczniowi wobec jego nalegań, demonstrowanie własnej bezradności wobec ucznia: „nie wiem, co mam teraz zrobić"), zastępowanie (wykonywanie zadań, które powinien wykonać uczeń, pozbawianie ucznia możliwości decydowania, co do podjęcia działań własnych, znajdując wytłumaczenie w trudności zadań, zmęczeniu i słabości ucznia, proponowanie zastąpienia go w różnych czynnościach), idealizacja (podkreślanie w słowach i zachowaniu przekonania o szczegól-

${ }^{6}$ Zob. M. Śnieżyński, Dialog edukacyjny, Kraków 2001; M. Śnieżyński (red.), Pedagogika w katechezie, Kraków 1998.

7 Zob. K. J. Szmidt, Twórczość i pomoc w tworzeniu w perspektywie pedagogiki społecznej, Łódź 2001; tenże, Szkice do pedagogiki twórczości, Kraków 2001; K. J. Szmidt, M. Modrzejewska-Śmigulska, Psychopedagogika działań twórczych, Kraków 2005; K. J. Szmidt, K. T. Piotrowski (red.), Nowe teorie twórczości. Nowe metody pomocy w tworzeniu, Kraków 2002; R. Wiechnik, Intelektualne i kreatywne aspekty zdolności do uczenia się, Lublin 1996.

${ }^{8}$ Zob. J. Bagrowicz, Edukacja religijna wspótczesnej młodzieży, Torun 2000; tenże, Towarzyszyć wzrastaniu. $Z$ dyskusji o metodach i środkach edukacji religijnej młodzieży, Toruń 2006.

${ }^{9}$ Zob. A. J. Cropley, Creativity in Education and Learning, London 2001; A. S. Fishkin, B. Cramond, P. Olszewski-Kubilius (red.), Investigating creativity in youth. Research and methods, New Jersey 1999; J. Khatena, Enhancing Creativity of Gifted Children. A Guide for Parents and Teachers, New Jersey 2000; M. D. Lynch, C. R. Harris (red.) Fostering Creativity in Children, K-8. Theory and Practice, Boston 2001; E. Nęcka, Psychologia twórczości, Gdańsk 2001; S. Popek, Człowiek jako jednostka twórcza, Lublin 2001; M. A. Runco (red.), The Creativity Research Handbook, New York 1997; A. E. Sękowski, Osiagnięcia uczniów zdolnych, Lublin 2000; A. J. Starko, Creativity in the Classroom. Schools of Curious Delight, New Jersey: 2001; R. J. Sternberg (red.), Handbook of Creativity, Cambridge 1999; K. J. Szmidt, M. Modrzejewska-Śmigulska, Psychopedagogika działań twórczych, Kraków 2005; K. J. Szmidt, K. T. Piotrowski (red.), Nowe teorie twórczości. Nowe metody pomocy w tworzeniu, Kraków 2002.

${ }^{10}$ E. Jarosz, E. Wysocka, dz. cyt., s. 296-300. 
nych walorach i możliwościach ucznia, przejawianie afektacji w kontakcie z uczniem, niezróżnicowane cenienie wszystkich spraw ucznia, brak krytycyzmu, co rzutuje na maksymalizację ocen pozytywnych) i niekonsekwencja (przemienność wrażeń i odczuć, brak konsekwencji w egzekwowaniu zadań nałożonych przez wychowawcę na ucznia) ${ }^{11}$.

Konsekwencją błędnych zachowań nauczyciela są głównie zmiany w strukturze poznawczej uczniów (osłabianie empatii, wzmacnianie zachowań egoistycznych) oraz pogarszanie obrazu nauczyciela (przestaje być autorytetem i tym samym obniża się jego zdolność do oddziaływania na ucznia). Wiadomo, że akceptacja ucznia jest źródłem energii życiowej, poczucia własnej wartości i bezpieczeństwa, ale ekstremalna emocjonalna akceptacja ucznia („,błędy ciepłe”) formuje w nim nastawienie egoistyczne, powoduje silne uzależnienie uczuciowe od nauczyciela, zawyża samoocenę ucznia i czyni go mało odpornym na stres. Uczeń taki w trudnej sytuacji nie jest zdolny do dojrzałego funkcjonowania (reaguje przesadnym gniewem, kieruje się własnymi potrzebami bez zrozumienia potrzeb innych).

Przedstawione kryteria dotyczące błędów popełnianych przez nauczycieli przy stosowaniu różnych metod pedagogicznych mają postać skrajną. W rzeczywistości występują zwykle różne stopnie nasilenia takich zachowań. W ich obszarze znajduje się takie nasilenie błędnych zachowań, które można określić mianem harmonii (umiaru, symetrii, racjonalnego środka). Takie harmonijne zachowanie wychowawcy wyraża zdolność do zrównoważonej koncentracji na sobie i partnerze interakcji (uczniu) oraz umiejętność opanowania skrajnych emocji wobec niego.

Jak się wydaje, potrzebna jest jakaś zobiektywizowana forma oceny zalet i błędów nauczyciela. W przypadku oceny błędów kluczowa wydaje się ocena dokonana przez samych uczniów. Jednak sama taka ocena, bez innych zobiektywizowanych opinii, posiada względną trafność. W celu wyeliminowania wpływu różnych ubocznych zmiennych (niestabilność samooceny uczniów w wieku młodzieńczym, hiperkrytycyzm w stosunku do autorytetów, krytyczne postrzeganie szkoły, zainteresowanie uczniów określonymi tematami a deprecjacja innych, itd.) oceny dokonywanej przez uczniów najlepsza jest metoda eksperymentu. Eksperyment umożliwia bowiem eliminację zmiennych zakłócających ocenę (chwilowy nastrój ucznia, kierowanie się uprzedzeniami, kierowanie się $\mathrm{w}$ ocenie subiektywnie pojmowanymi kryteriami oceny, chęć przypodobania się nauczycielowi lub pragnienie ukarania go) poprzez zastosowanie zmiany w jednym czynniku (zmiana metody prowadzenia lekcji), a pozostawieniu innych niezmienionych (tacy sami uczniowie, takie same tematy, takie same wymagania, taki sam czas, itd.).

${ }^{11}$ Szerokie omówienie i ocena w cytowanym powyżej dziele A. Guryckiej. 
Eksperyment umożliwia ingerencję w jeden czynnik i obserwację zmiany oceny uczniów. Ma to na celu eliminację czynnika niestabilności ocen dokonywanych przez respondentów.

Stosowanie metody dialogicznej, jak się wydaje, jest obecnie z jednej strony wyzwaniem dla nauczycieli, a z drugiej, ryzykowną koniecznością. Wyzwaniem, ponieważ nie można myśleć o dobrych skutkach oddziaływań pedagogicznych, kiedy uczeń nie będzie podmiotem tych działań. Główne ryzyko polega zaś na groźbie zastosowania różnych błędów, zarówno tych ciepłych (idealizacja, zastępowanie), jak i zimnych (kiedy nauczyciel doświadczy przykrych emocji związanych z odczuciem braku kontroli nad uczniami). Postanowiono sprawdzić efektywność oddziaływań pedagogicznych przy zastosowaniu eksperymentu (w pierwszym etapie stosowanie metody dialogicznej oraz dokonanie oceny jej przez uczniów a w drugim etapie zmiana na metodę podającą i obserwacja zmiany oceny dokonywanej przez uczniów).

Celem pracy będzie odpowiedź na następujące pytanie badawcze: Czy zmienna niezależna, jaką jest stosowanie przez nauczyciela różnych metod pedagogicznych, wpływa istotnie na zmianę oceny uczniów? W stosunku do tak postawionego pytania wysunięto następującą hipotezę badawczą: stosowanie metody dialogicznej przez nauczyciela wpływa istotnie na poprawę oceny nauczyciela we wszystkich aspektach oceny wydawanej przez uczniów.

\section{Metoda badawcza}

Badania miały charakter próby eksperymentalnej na tej samej grupie osób (test, a po upływie 1 roku retest). Technika ta ma charakter przyczynowy (causal research), gdyż na podstawie zaobserwowanych skutków prowadzi do rozpoznania przyczyn. Celem tego eksperymentu była obserwacja zmiany oceny uczniów wobec nauczyciela (zmienna zależna - skutek), która dokonywała się na skutek manipulacji metodami pedagogicznymi przez niego stosowanymi (zmienna niezależna - przyczyna). Ingerując w różne aspekty stosowanych przez nauczyciela metod obserwowano zmiany w ocenach uczniów.

W pierwszym etapie nauczyciel stosował metodę dialogiczną a w drugim podająca. Zastosowanie takiej strategii badawczej (najpierw metoda dialogiczna a potem podająca) wynikało z założenia, że odwrotna kolejność stosowania metod (najpierw metoda podająca a potem dialogiczna) mogłaby istotnie wpłynąć na uzyskane efekty badawcze (sam efekt luźniejszych lekcji i lepszej atmosfery mógłby zniekształcać trafność innych aspektów oceny 
uczniów, na przykład oceny merytoryki, komunikatywności, poglądowości, dyscypliny, itd.).

W metodzie dialogicznej (pierwszej w kolejności) modyfikacji uległy następujące elementy metody podającej (druga w kolejności):

- aktywizacja uczniów w sferze dydaktycznej i organizacyjnej (przygotowanie referatów dotyczących tematów skorelowanych z przedmiotami plastycznymi i ogólnymi, to jest historią i językiem polskim; wykład nauczyciela pogłębiający i uzupełniający referat przygotowany przez ucznia),

- aktywizacja uczniów w sferze wychowawczej (merytoryczna ocena referatu przez kolegów i koleżanki w zakresie realizacji tematu - nauczyciel jako facylitator a nie kontroler poprawności oceny).

Do pomiaru zmian oceny uczniów zastosowano sprawdzone pod względem psychometrycznym narzędzie badawcze własnej konstrukcji, to jest Kwestionariusz Metody Dialogicznej (KMD). Składa się on z dziewięciu itemów, które uczniowie anonimowo wypełniają pod koniec roku szkolnego. Każdy item uzyskuje ocenę od 1 do 5, która określa nasilenie poszczególnych elementów metody dialogicznej realizowanej przez nauczyciela. Itemy od pierwszego do siódmego diagnozują różne aspekty metody dialogicznej. Ósmy item stanowi o specyfice danego przedmiotu (w tym przypadku jest nim religia). Dziewiąty item służy wyrażeniu przez uczniów zgeneralizowanej oceny umiejętności pedagogicznych nauczyciela.

Narzędzie to bada następujące aspekty metody dialogicznej: 1) ATM atmosfera na lekcjach (od przyjaznej do wrogiej), 2) METOD - stosowanie metod (od podającej do dialogicznej), 3) KOM - sprawność komunikacji, 4) MERYT - poziom merytoryczny, 5) TRAF - trafność tematyki, 6) POGL poglądowość (posługiwanie się materiałami poglądowymi), 7) DYSC - dyscyplina na lekcjach, 8) RELIG - związek tematyki z religią (przedmiotem lekcji), 9) OCENA - ogólna ocena prowadzonych zajęć.

\section{Opis grupy i sposób przeprowadzenia badań}

Badania przeprowadzono samodzielnie $\mathrm{w}$ grupach klasowych (około 20 osób) na koniec roku szkolnego ( $\mathrm{N}=250$ ) przez dwa kolejne lata (pierwszy etap 2003/2004, drugi etap 2004/2005). Badania miały charakter anonimowy. Grupa badawcza to uczniowie Zespołu Państwowych Szkół Plastycznych w Krakowie. Granice wiekowe znajdują się w przedziale pomiędzy 13 a 20 rokiem życia. $75 \%$ badanej młodzieży to kobiety, a reszta to mężczyźni.

Do badań zastosowano analizę średnich arytmetycznych, frekwencji (częstości wyborów poszczególnych ocen przez uczniów) oraz test Chi kwa- 
drat. W opracowaniu danych statystycznych posłużono się pakietem programów statystycznych SPSS.

\section{Wyniki badań własnych}

Przeprowadzone analizy służą weryfikacji przedstawionych hipotez badawczych, dotyczących dokonywanej pod koniec roku szkolnego oceny efektywności metod dydaktyczno-wychowawczych stosowanych przez nauczyciela.

A. W pierwszej kolejności zaprezentowano wyniki ocen dokonywanych przez uczniów dotyczących stosowania metody dialogicznej przez nauczyciela prowadzącego.

Wyniki analiz statystycznych pokazują, że najwyższe oceny dokonywane przez uczniów dotyczą skali 2. (metoda podająca ver. dialogiczna: dla ok. 80\% uczniów - metoda dialogiczna), skali 1. (atmosfera przyjazna-wroga: dla ok. 80\% uczniów - atmosfera przyjazna), ogólnej oceny $(\mathrm{M}=4,24$; $\mathrm{SD}=$ $=0,84$ ) oraz 4 . (poziom nowatorski ver. banalny: dla $40 \%$ - poziom nowatorski). Przeciętne oceny pojawiły się w skali 3. (sprawność komunikowania zrozumiała ver. niezrozumiała: dla ok. 70\% uczniów - komunikatywność zrozumiała), 6. (poglądowość wystarczająca ver. mała: dla ponad 50\% uczniów - wystarczająca) i 7. (dyscyplina słaba ver. rygoryzm: dla prawie $50 \%$ - atmosfera słaba). Natomiast oceny bliskie średniej uwidoczniły się w skali 5. (trafność tematyki - życie ver. abstrakcja: dla ok. 40\% uczniów - tematyka związana z życiem) i 8. (związek z religią ścisły ver. mały: dla $40 \%$ uczniów tematyka mocno związana z religią). Oznacza to, że w opinii uczniów nauczyciel w zdecydowany sposób stosował metodę dialogiczną. Na prowadzonych przez niego lekcjach atmosfera była przyjazna, a poziom merytoryczny lekcji był wartościowy poznawczo. W związku z tym nauczyciel otrzymał ogólną ocenę wysoką (cztery z plusem). W mniejszym stopniu uczniowie rozumieli treści przekazywane na lekcjach. Ponadto tematy poruszane na lekcjach były im przeciętnie bliskie, słabo związane z realnym życiem oraz religijnością przez nich doświadczaną.

Oceny uczniów były najbardziej zróżnicowane w dziedzinie oceny dyscypliny (duża lewostronna skośność rozkładu, około 20\% uczniów uważa, że dyscyplina jest za duża). W pozostałych skalach zróżnicowanie było stosunkowo słabe. Oznacza to, że ocena dyscypliny na lekcjach stanowi element trudny do jednoznacznej oceny (dla jednych jest zbyt duża, dla innych wystarczająca a dla pozostałych - słaba i przeszkadzajaca). W pozostałych aspektach oceny nie były rozproszone. Sugeruje to, że we wszystkich aspek- 
tach stosowanej przez nauczyciela metody dialogicznej oceny uczniów były zgodne, co do swojej trafności.

B. W drugiej kolejności, zgodnie z założeniami eksperymentalnymi, przedstawiono zmiany wyników ocen dokonywanych przez uczniów wynikające ze zmiany stosowanej przez nauczyciela metody prowadzenia zajęć (w pierwszym etapie dialogiczna, w drugim - metoda podająca).

Wyniki porównawczych analiz statystycznych pokazały, że zmieniły się istotnie oceny uczniów w sześciu (na dziewięć) skalach tj. w skali 2. (metoda podająca ver. dialogiczna: $C h i=37,004 ;$ p.i. $=0,001)$, 9. (ocena ogólna: $C h i=25,973 ;$ p.i. $=0,001), 7$. (dyscyplina słaba ver. rygoryzm: $C h i=17,150$; p.i. $=0,002), 8$. (związek z religią ścisły ver. mały: $C h i=14,783 ;$ p.i. $=0,005)$, 1. (atmosfera przyjazna-wroga: $C h i=12,930 ;$ p.i. $=0,012)$ i 6 . (poglądowość wystarczająca ver. mała: $C h i=9,451$; p.i. $=0,051)$. Ujawnia to, że metoda stosowana przez nauczyciela $\mathrm{w}$ drugim etapie eksperymentu była $\mathrm{w}$ istocie bardziej podająca niż dialogiczna. Fakt ten uwidocznił się nasiloną dyscypliną panującą podczas lekcji i gorszą atmosferą panującą na zajęciach, która była dla uczniów mniej przyjazna. W stosowanej metodzie podającej ujawniał się silniejszy związek poruszanych na zajęciach treści z religią, ale równocześnie lekcje były mniej bliskie emocjonalnie uczniom, bardziej ubogie oraz mniej ubarwione poglądowością. Uczniowie oceniali nauczyciela przy stosowaniu metody podającej zdecydowanie mniej pozytywnie.

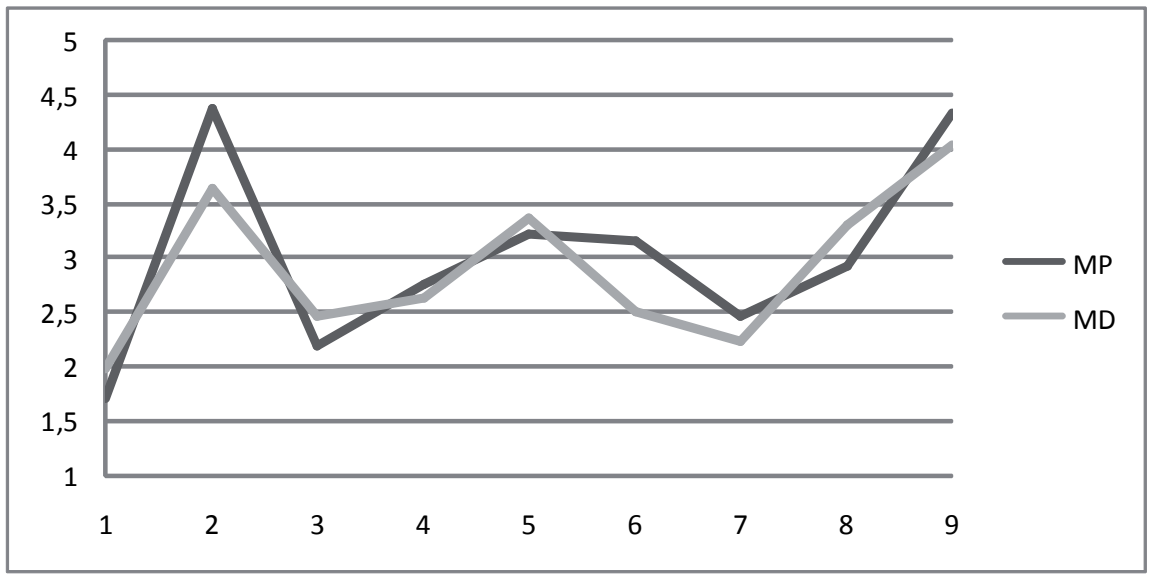

Wykres 1. Średnie oceny uczniów dotyczące stosowania przez nauczyciela metody dialogicznej (MD) ver. podającej (MP)

Istotne zmiany ocen nie ujawniły się w trzech (na dziewięć) skalach to jest w skali 3. (komunikacja zrozumiała ver. niezrozumiała), 4. (poziom 
nowatorski ver. banalny) i 5. (trafność tematyki - życie ver. abstrakcja). Pojawiły się jednak pewne tendencje w tych skalach. Oznacza to, że przy stosowaniu przez nauczyciela obu metod uczniowie w podobnym stopniu rozumieją nauczyciela, ale mają tendencję do lepszego rozumienia w metodzie dialogicznej. W jednej i drugiej metodzie podobny jest także poziom merytoryczny występujący na lekcjach, ale w metodzie dialogicznej jest nieco wyższy. Treści poruszane w trakcie lekcji są równie związane z życiem tak w jednej, jak i w drugiej metodzie, ale przy stosowaniu metody dialogicznej są nieco bliższe uczniom.

\section{Dyskusja wyników}

Podjęta procedura badawcza i analiza materiału empirycznego uzyskanego wśród młodzieży potwierdziła hipotezę badawczą w niektórych aspektach. Hipoteza (Stosowanie metody dialogicznej przez nauczyciela wpływa istotnie na zmianę oceny we wszystkich aspektach oceny uczniów) znalazła silne potwierdzenie (istotny wpływ ujawnił się w 6 na 9 aspektów ocen). Udowodniono więc w ten sposób, że wprowadzone innowacje metodyczne (metoda dialogiczna ver. podająca) spowodowały istotne zmiany w ocenach uczniów w zakresie następujących aspektów: metoda, dyscyplina, tematyka, atmosfera, poglądowość i ogólna ocena nauczyciela. Hipoteza badawcza nie znalazła potwierdzenia w 3 aspektach oceny uczniów: komunikacja, poziom merytoryczny i trafność tematyki.

Wydaje się, że postawiony problem badawczy został w dużej mierze rozstrzygnięty. Udowodniono bowiem istnienie silnego wpływu oddziaływań nauczyciela (przyczyna) na ocenę uczniów (skutek). Osiagnięte rezultaty badawcze pokazuja, że zgodnie z przedstawionymi założeniami teoretycznymi dotyczącymi metody dialogicznej, jej stosowanie prowadzi do wyraźnego wzrostu oceny nauczyciela (ocena ogólna istotnie wyższa). Uczniowie wydając swoje oceny uchwycili zmianę metody dialogicznej na podająca (istotna zmiana w ocenie dotyczącej stosowania określonej metody przez nauczyciela). Ponadto dostrzegli zalety metody dialogicznej, która była im zdecydowanie bliższa emocjonalnie (lepsza atmosfera, bliskość emocjonalna tematyki). Uczniowie w swych ocenach dali wyraz swoim odczuciom, że stosowanie metody dialogicznej wiąże się z pewnymi problemami natury dydaktycznej i wychowawczej (niedokładna realizacja programu nauczania, słabe zdyscyplinowanie niektórych uczniów).

Wprowadzone innowacje metodyczne nie spowodowały żadnych zmian w zakresie poziomu merytorycznego zajęć (zachowany poziom nowatorski) oraz komunikatywności nauczyciela i trafności tematycznej (nieco 
abstrakcyjna, ale związana z życiem). Oznacza to, że stosowanie metody dialogicznej nie zubaża procesu dydaktycznego, nie wpływa negatywnie na poziom merytoryczny lekcji, chociaż występuje większe niezdyscyplinowanie uczniów oraz braki w ścisłej realizacji programu. Można z tego wnosić, że w samej ocenie uczniów zarzuty stawiane metodzie dialogicznej są bezpodstawne: rezygnacja ze ścisłego trzymania się konspektu lekcji, akceptacja ingerencji uczniów w przebieg lekcji, a czasem nadużywanie przez nich wolności nie prowadzi bezpośrednio do negatywnych skutków. Uzyskane wyniki są zgodne z wynikami innych badań w tym zakresie, że stosowanie metody dialogicznej nie tylko nie osłabia efektywności prowadzenia zajęć, ale w długoterminowej perspektywie ją wzmacnia (stosowanie metody dialogicznej wzmacnia zdolności twórcze uczniów oraz prowadzi w konsekwencji do dojrzałości).

Zaskakujący jest natomiast wniosek dotyczący braku wpływu zmiany metody prowadzenia lekcji na komunikatywność nauczyciela i trafność tematyki. Okazuje się, że zarówno przy stosowaniu metody dialogicznej, jak i podającej uczniowie $\mathrm{w}$ podobnym stopniu rozumieją nauczyciela a przekazywane na lekcjach treści są słabo związane z życiem uczniów oraz zbyt odległe od ich zainteresowań (zbędne, nieciekawe, nudne, itd.). Również ten fakt przemawia, jak się wydaje, na korzyść metody dialogicznej, ponieważ stosowana metoda $\mathrm{w}$ sporej części była powiązana $\mathrm{z}$ elementami metody podającej. Stosowanie metody podającej, mimo że przeplecione z elementami metody dialogicznej, prowadzi do tego, że niektórzy uczniowie nie dostrzegają sensowności nauki w szkole. Pojawia się wniosek, że uczniowie powinni być - zgodnie z założeniami metody dialogicznej - w dużej rozciągłości zaangażowani w sferę organizacyjną lekcji (przygotowanie przez nich tematów bardziej związanych z ich życiem przy konsultacji z nauczycielem prowadzącym). Wtedy dla nich lekcje będą inspirujące, interesujące i perspektywicznie sensowne.

Patrząc syntetycznie na uzyskane rezultaty badawcze, należy stwierdzić, że w istotnym stopniu potwierdziły one skuteczność i efektywność stosowania metody dialogicznej, a podważyły sensowność zarzutów stawianych tej metodzie (ocena uczniów okazała się zbieżna z założeniami teoretycznymi metody dialogicznej i nie potwierdziła zarzutów stawianych tej metodzie). Trafność uzyskanych wniosków wzmacnia dodatkowo wiarygodność uzyskanych wyników, która ujawnia się nie tylko w aspekcie metodologicznym (dobór grupy, stosowanie sprawdzonych narzędzi badawczych, analizy statystyczne), ale i treściowym (uczniowie nie fascynowali się metodą dialogiczną, ale oceniali ją w sposób zróżnicowany i krytyczny). Nasuwa się więc wniosek, że wprawdzie przy stosowaniu metody dialogicznej mogą występować pewne problemy (słabsza efektywność działań dydaktycznych, 
niezdyscyplinowanie niektórych uczniów, mniejsza skuteczność egzekwowania), ale w ogólnej ocenie negatywne skutki uboczne są do akceptacji w związku z nasilonym występowaniem pozytywnych zjawisk (lepsza atmosfera, bliskość emocjonalna tematyki, lepsza ocena dla nauczyciela, brak negatywnych skutków w aspekcie poziomu merytorycznego).

Uzyskane rezultaty badawcze mają wstępny i niezupełny charakter. Wydaje się, że istnieje potrzeba uzyskania dalszych potwierdzeń tezy, że stosowanie metody dialogicznej nie prowadzi do zubożenia poznawczego uczniów, a raczej do ich rozwoju. A ponadto pozytywnie wpływa na efekty organizacyjne, dydaktyczne i wychowawcze lekcji (spontaniczna, niekierowana współpraca uczniów, ich samodzielne poszukiwania i myślenie, lepsze posługiwanie się uzyskaną $\mathrm{w}$ trakcie lekcji wiedzą, wzmacnianie uzdolnień twórczych ucznia, itd.). Pojawia się też potrzeba przeprowadzenia takich badań, które uwzględniając zobiektywizowane narzędzia badawcze ${ }^{12}$, mierzące różne aspekty osiagnięć uczniów, ukazałyby w szerszej perspektywie pozytywny wpływ stosowania metody dialogicznej. Zwłaszcza te, które wiążą się z ryzykownymi skutkami ubocznymi prowadzenia zajęć metodą dialogiczną (słaba dyscyplina, brak dobrej organizacji, słaby związek z tematyką, itd.).

\section{The Effectiveness of the Dialogical Method in Religious Education (Summary)}

This article validates the role of dialogical methods in religious education. Pedagogical and psychological research suggests that a dialogue between teachers and students is essential to facilitating the development of critical and creative consciousness. An experiment was conducted to predict the effectiveness of the dialogical method in religious education. 250 students took part in a survey compiled for the purpose of the test. Descriptive statistics was applied to carry out the survey analysis. The results confirmed that a student-centered dialog is an effective method in religious education.

12 E. Jarosz, E. Wysocka, dz. cyt., s. 204-224. 